https://doi.org/10.11646/zootaxa.4294.5.2

http://zoobank.org/urn:lsid:zoobank.org:pub:864CBCC4-220A-4BB4-B904-CFBA17F19CEE

\title{
A new species of the catfish genus Cordylancistrus (Siluriformes, Loricariidae) from the Magdalena River, Tolima, Colombia
}

\author{
FRANCISCO PROVENZANO R. ${ }^{1,2}$ \& FRANCISCO A. VILLA-NAVARRO ${ }^{3}$ \\ ${ }^{1}$ Centro Museo de Biología, Instituto de Zoología y Ecología Tropical, Facultad de Ciencias, Universidad Central de Venezuela, Apar- \\ tado 47058, Caracas 1041-A, Venezuela. \\ ${ }^{2}$ Instituto de Ciencias Biológicas, Escuela Politécnica Nacional, Quito, Ecuador E-mail: fprovenz@gmail.com \\ ${ }^{3}$ Grupo de Investigación en Zoología, Facultad de Ciencias, Universidad del Tolima, Ibagué, Colombia. E-mail: favilla@ut.edu.co
}

\begin{abstract}
A new species of catfish is described from Colombia, and provisionally assigned to the genus Cordylancistrus. The new species is most similar to $C$. perijae and C. nephelion from Venezuela. The description is based on ten specimens collected from tributaries of the Magdalena River which drain the eastern slope of the Cordillera Central and the western slope of Cordillera Oriental, in the Department of Tolima. The new species is the first Cordylancistrus described from the Magdalena River basin. With this discovery, the number of Cordylancistrus species in Colombia increases to three. The geographic distribution of the species suggest that Andean orogenesis played an important role in the diversification of the group.
\end{abstract}

Key words: Fishes, Catfishes, Taxonomy, Biodiversity, South America

\section{Resumen}

Se describe una nueva especie de bagre para Colombia, y provisionalmente, se asigna al género Cordylancistrus. La nueva especie es más similar a $C$. perijae y $C$. nephelion de Venezuela. La descripción se basa en diez ejemplares colectados en afluentes del río Magdalena, que drenan la vertiente oriental de la Cordillera Central y la vertiente occidental de la Cordillera Oriental, en el Departamento de Tolima. La nueva especie es el primer Cordylancistrus descrito para la cuenca del río Magdalena. Con este hallazgo, el número de especies de Cordylancistrus, en Colombia, aumenta a tres. La distribución geográfica de las especies sugiere que la orogenia andina jugó un papel importante en la diversificación del grupo.

\section{Introduction}

This article presents the description of a new species, provisionally assigned to the genus Cordylancistrus. Species that were originally assigned to the genus Cordylancistrus inhabit mountain rivers in Venezuela, Colombia and Ecuador (Isbrücker, 1980; Perez \& Provenzano, 1996; Provenzano \& Milani, 2006; Tan \& Armbruster, 2012). Three species are present in Venezuela: C. torbesensis (Schultz, 1944), type species of the genus, Orinoco River basin, C. perijae Perez \& Provenzano, 1996, Maracaibo Lake basin, and C. nephelion Provenzano \& Milani, 2006, Caribbean Sea basin. Two species are known from Colombia, C. daguae (Eigenmann, 1912), Pacific slope of the Cordillera Occidental, and C. platyrhynchus (Fowler, 1943) from the Amazon River basin, Atlantic slope of the Cordillera Oriental. Cordylancistrus platyrhynchus was transferred to the genus Chaetostoma (Armbruster, 2004). Ecuador had two described species, but recently, Lujan, Meza-Vargas \& Barriga-Salazar (2015) proposed two new genera Andeancistrus and Transancistrus for these species. Cordylancistrus platycephalus (Boulenger, 1898), from the Amazon River basin, is now Andeancistrus platycephelus, and Cordylancistrus santarosensis Tan \& Armbruster, 2012, from the Pacific slope, is now Transancistrus santarosensis. Lujan, Meza-Vargas \& BarrigaSalazar (2015) also assign to Transancistrus, the species Chaetostoma aequinoctiale Pellegrin, 1909, from the 
Pacific slope, and describe a new species Andeancistrus eschwartzae, from the Amazon River basin. These results elevate to four the number of species in Ecuador, and to eight or nine the total of species known.

No diagnostic characters have been proposed to define Cordylancistrus, and available phylogenetic studies indicate that species assigned to Cordylancistrus are polyphyletic. But on the other hand, species belonging to the genera Andeancistrus, Chaetostoma (including the genera Lipopterichthys and Loraxichthys), Cordylancistrus, Dolichancistrus, Leptoancistrus and Transancistrus, form a well-supported clade, the Chaetostoma group (Armbruster, 2004, 2008) or Chaetostoma Clade (Lujan et al., 2015a, b). The external morphology of some species of Cordylancistrus seems to indicate they are more related to each other than with other species included in Chaetostoma group. We agree with Ambruster $(2004,2008)$ and with Lujan et al. $(2015 \mathrm{a}, \mathrm{b})$, that a comprehensive phylogenetic analysis that includes all species of Andeancistrus, Cordylancistrus, Dolichancistrus, Leptoancistrus and Transancistrus is needed to establish the status of each genus adequately. In the meantime, and for our diagnosis and comparative analysis, we used the nine species listed above.

\section{Materials and methods}

Specimens used in comparisons are listed in material examined. Morphometric and meristic comparisons with other species included in the Chaetostoma group were made based on the data available in the literature and specimens at our hand. Measurements were made point to point with dial calipers to the nearest $0.1 \mathrm{~mm}$. Counts and measurements were made on the left side of specimens whenever possible. Standard length is expressed in $\mathrm{mm}$. All other measurements are expressed as percents of standard length. Measurements follow Boeseman (1968), Perez \& Provenzano (1996) and Provenzano \& Milani (2006). Sex was identified via characters in Rapp Py-Daniel (1991), Ballen (2011) and Lujan, et al. (2015b) so that sexually dimorphic characters could be determined. Institutional abbreviations are as listed in Sabaj (2016).

\section{Results}

\section{Cordylancistrus pijao, new species}

Figure 1,2 Tables 1,2

Holotype. CZUT-IC 1292, $114.8 \mathrm{~mm}$ SL, Colombia, Departamento de Tolima, Municipio Villarrica, Vereda La Arcadia, Magdalena River basin, Prado River system, Quebrada Aguas Blancas at its mouth in the Cuinde Blanco River, 0355’29.6”N 74³6’40.8”W, 950 m asl, L.J. García-Melo, 13 November 2004.

Paratypes. All from Colombia. Departamento de Tolima, Magdalena River basin: CZUT-IC 1660, $53.2 \mathrm{~mm}$ SL, same data as the holotype. CZUT-IC 1723, 1 C\&S, $84.4 \mathrm{~mm}$ SL, same data as the holotype. MBUCV-V-32974, 117.6 mm SL, same data as the holotype. CZUT-IC 3999, $41.3 \mathrm{~mm}$ SL, Municipio Mariquita, Vereda Flor Azul, Quebrada Aguasal tributary of the Gualí River, $05^{\circ} 12^{\prime} 26.5^{\prime} \mathrm{N} 74^{\circ} 59^{\prime} 0.3^{\prime \prime} \mathrm{W}, \mathrm{F}$. A. Villa-Navarro and N. Oviedo, 08 April 2010. CZUT-IC 5174, $141.0 \mathrm{~mm}$ SL, Municipio San Antonio, Vereda Pringamosal, Saldaña River system, Cucuana River, $04^{\circ} 01^{\prime} 32.7^{\prime} \mathrm{N} 75^{\circ} 28^{\prime} 17,4$ 'W, L. J. García-Melo and N. Oviedo, 18 February 2011. CZUT-IC 7278, 2 ex. 115.9-151.6 mm SL, Municipio San Antonio, Saldaña River system, Cucuana River downstream of the Vereda Florida, $04^{\circ} 02^{\prime} 20.6 ” \mathrm{~N}$ 75²6’29.5”W, $1200 \mathrm{~m}$ asl, Y. López Pinto, June 2008. MBUCV-V-35677, 122.8 mm SL, Municipio San Antonio, Vereda Florida Baja, Saldaña River system, Cucuana River, Y. López Pinto, 20 July 2008. MBUCV-V-35678, 147.5 mm SL, Municipio Roncesvalles, Vereda Pringamosal, Saldaña River system, Cucuana River, under the hanging bridge, 0401’33.1”N 75²8’17.1”W, Y. López Pinto, 01 June 2008.

Diagnosis. Cordylancistrus pijao n. sp. lacks a unique distinctive character for accurate identification. Between its congeners is distinguished from Cordylancistrus torbesensis by an absence of plates on the ventral border of the snout ( $v s$. ventral border of the snout covered with plates), and by the longest movable odontodes not reaching the pectoral-fin origin ( $v s$. longest movable odontodes extending beyond the pectoral-fin origin); from $C$. platyrhynchus by the presence of developed and evident evertibles cheek odontodes (vs. odontodes vestigial or almost imperceptible); from $C$. daguae by having the adpressed dorsal fin not reaching adipose-fin origin (vs. adpressed dorsal fin reaching adipose-fin origin), and by having a greater postdorsal length (26.8\% $-31.2 \%$ SL vs. $34.6 \%-39.8 \%$ SL; see Table 2); from $C$. nephelion and $C$. perijae by having a different color pattern: $C$. pijao has 
the dorsal and lateral sections of head and body light brown or beige with rounded or elongated dark (black) blotches, sometimes faded or barely visible, without a definite pattern while $C$. nephelion has the dorsal and lateral sections of the head and body blackish to greenish brown with numerous white irregular spots and C. perijae has the dorsal surface of head and body uniformly brown. It is distinguished from Andeancistrus platycephalus by the absence of spiny keels on the lateral plates of the body ( $v$ s. lateral plates with spiny keels); from A. eschwartzae by the snout covered with bony plates, except at the tip ( $v s$. snout completely covered with plates), by a longer posterior body region, narrower body, and shorter dentary (postdorsal length $34.6 \%-39.8 \%$ SL $v$ s. 31.3\%-34.9\% SL; cleithral width $30.3 \%-37.7 \%$ SL vs. $37.4 \%-40.8 \%$ SL, dentary length $8.4 \%-10.2 \%$ SL $v s .11 .6 \%-12.8 \%$ SL; see Table 2); from Transancistrus santarosensis and T. aequinoctiale by the snout covered with bony plates, except at the tip ( $v s$. lateral edges and partial dorsal region of the snout naked).

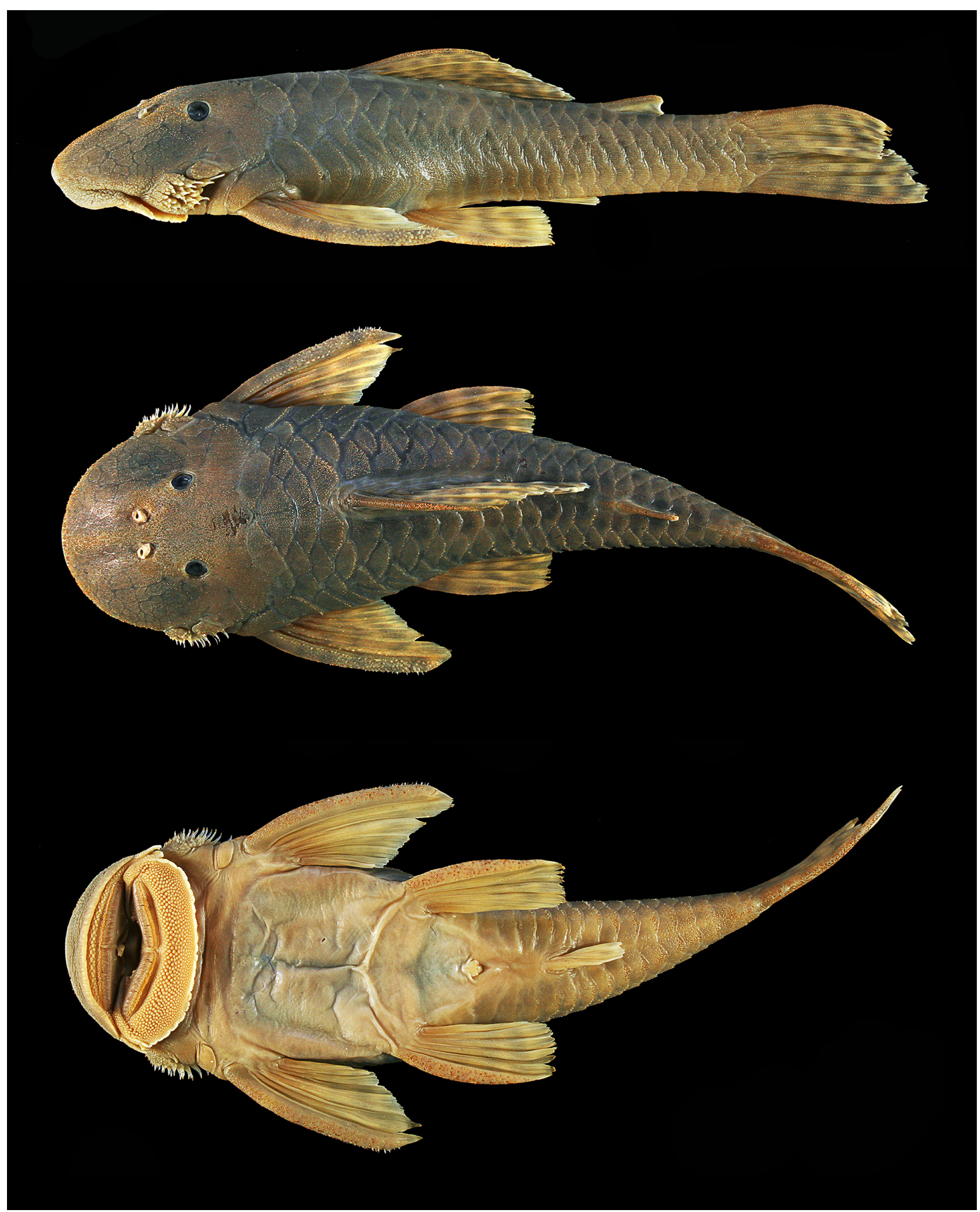

FIGURE 1. Cordylancistrus pijao, CZUT-IC 1292, holotype, 114.8 mm SL. 
Description. Morphometric data given in Table 1. Body robust and deep. Caudal peduncle compressed and high. Dorsal profile of body from tip of snout through dorsal-fin origin slightly convex, then gradually descending straight to caudal-fin origin. Ventral profile of body flat and straight. Caudal peduncle with five longitudinal rows of bony plates. Ventral edges of the caudal peduncle slightly angular. Head broad and slightly depressed. In dorsal view, the outline of the head is rounded. Bony plates of body sides without spiny keels. Lateral line bony plates 2425. Postanal plates 9-10. Interdorsal plates 4-5, the last with slight keel. Ventral surface of head and abdomen naked to anal-fin origin. Urogenital papilla present, located posterior the anus, shows different shape according sex. Snout covered with small bony plates, except tip, larger specimens have naked strip with odontodes on snout edge. Nostrils juxtaposed and closer to eyes than tip of snout. The anterior nostril easy visible but posterior partially covered with flap of skin. Eyes small, located dorsolaterally. Orbits ringed with very small odontodes. Interorbital space flat or gently convex. Posterior edge of supraoccipital without fleshy keel. Interopercular region with visible rosette of numerous hypertrophied evertible odontodes. Area anterior to hypertrophied cheek odontodes not covered by bone plates. Hypertrophied cheek odontodes straight with curved tip, 27-39, increase in number with size; longest, most posterior hypertrophied odontodes do not reach pectoral-fin origin. Mouth wide. Lip surfaces papillose. Papillae of upper lip slightly larger. Posterior lip edge with evident undulations, border of each undulation irregular. Maxillary barbel very short, almost two thirds of length attached to lower lip by fleshy fold. Distal third of the maxillary barbel free. Premaxilla and dentary very wide, almost of same size. Inside mouth, behind teeth, slight fleshy projections present. Numerous teeth, 64-147 teeth in premaxilla and 82-170 teeth in dentary, increase in number with size; teeth thin and elongated, with curved tips towards inside the mouth. Teeth bicuspid with lobes more or less equal; and shovel-shape like. Cusp of each tooth bright yellow, base white.

All fins are well developed. The fin spines (or first ossified unbranched ray of each fin) and branched rays supporting odontodes, in some cases of appreciable size. Dorsal fin i,8. Depressed dorsal fin does not reach adipose-fin origin. In small specimens, dorsal-fin spinelet visible and covered with small odontodes. In large specimens, spinelet often covered by soft tissue. Anal fin with ii,4. The second unbranched ray of the anal fin is attached to the first, and is slightly longer. Caudal fin i,14,i. Its posterior border is obliquely truncated. Pectoral fin i,6. Pectoral-fin spine reaches one third of pelvic spine length. Pelvic fin i,5. Largest specimen $>150 \mathrm{~mm}$ TL, which is among the largest species of Chaetostoma group.

TABLE 1. Morphometric data of Cordylancistrus pijao, in $\%$ of standard length, $\mathrm{n}=10$.

\begin{tabular}{|c|c|c|c|c|c|}
\hline & Holotype & Average & STD & Min & Max \\
\hline $\mathrm{SL}(\mathrm{mm})$ & 114.8 & & & 41.3 & 151.6 \\
\hline Head length & 31.5 & 33.3 & 1.8 & 31.3 & 35.8 \\
\hline Predorsal length & 44.3 & 44.8 & 1.3 & 43.1 & 47.3 \\
\hline Postdorsal length & 36.8 & 36.5 & 1.7 & 34.6 & 39.8 \\
\hline Interdorsal length & 16.3 & 16.4 & 1.0 & 14.6 & 17.9 \\
\hline Preanal length & 68.1 & 70.3 & 2.1 & 68.0 & 74.7 \\
\hline Postanal length & 29.3 & 27.9 & 0.8 & 26.9 & 29.3 \\
\hline Thoracic length & 24.8 & 24.3 & 1.2 & 22.0 & 25.9 \\
\hline Abdominal length & 22.3 & 22.8 & 1.0 & 21.3 & 24.5 \\
\hline Dorsal fin base & 22.3 & 23.2 & 1.3 & 21.3 & 24.9 \\
\hline Dorsal spine length & 19.4 & 21.2 & 1.8 & 18.7 & 23.6 \\
\hline Pectoral spine length & 30.6 & 30.5 & 4.3 & 23.0 & 34.9 \\
\hline Pelvic spine length & 22.6 & 22.7 & 1.2 & 21.6 & 24.7 \\
\hline Cleithral width & 33.3 & 34.8 & 2.5 & 30.3 & 37.7 \\
\hline Caudal peduncle depth & 11.0 & 11.3 & 0.8 & 9.5 & 12.4 \\
\hline Head depth & 16.4 & 17.3 & 0.7 & 16.4 & 18.9 \\
\hline Snout length & 21.4 & 22.8 & 0.7 & 21.4 & 24.0 \\
\hline Interorbital width & 8.6 & 10.2 & 0.7 & 8.6 & 10.8 \\
\hline Orbital diameter & 3.1 & 3.4 & 0.4 & 2.7 & 3.9 \\
\hline Mandibular ramus length & 9.7 & 9.4 & 0.6 & 8.4 & 10.2 \\
\hline
\end{tabular}


Sexual Dimorphism. In large specimens (> $120.0 \mathrm{~mm} \mathrm{SL}$ ) differences in morphology of urogenital papilla, related to sex easy to observe. In females, urogenital papilla present as small fleshy cylinder with truncate end. In males, urogenital papilla present as small fleshy cone with pointed tip. Nuptial male with developed odontodes on snout edge and on spine and first two or three branched rays of pectoral-fin. These odontodes arranged in longitudinal rows, located on dorsal surface. Longest odontodes on distal end of pectoral spine. Also, spine of pelvic-fin with fleshy fold on posterodorsal surface that runs almost its entire length. First three or four branched rays of pelvic-fin with rows of developed odontodes, very similar to that described for pectoral fin. Females have some developed odontodes on spine and first two or three branched rays of pectoral-fin. Differences of urogenital papilla are permanent, but it is unknown if differences of pectoral and pelvic fins are temporary or permanent.

Color. Dorsal and lateral regions of head and body light brown or beige with irregular dark black blotches, sometimes faded or barely visible, without a definite pattern. In larger specimens, blotches seem organized in irregular longitudinal rows. Belly and ventral regions of head whitish. Surface posterior to anus, with same color as dorsal and lateral areas, but lighter. Ventral region of head and body without spots. All fin rays clear yellowish or brown with dark black bands or stripes. Interradial membranes hyaline. Dorsal-fin with four bands; distal edge of dorsal fin without pigment. Pectoral-fin with five to eight bands. Pelvic-fin with four or five bands. Bands observed on supporting elements of pectoral and pelvic fins visible ventrally. Anal fin with two diffuse bands. Caudal-fin with four to five bands. Distal edge of the caudal-fin translucent. In live specimen, fins have reddish tone (Fig. 2).

Geographical distribution. The localities where the specimens of Co. pijao were captured include: Cuinde Blanco River, a tributary of the Cunday River, which in turn drains to the Prado River, and the Gualí and Cucuana rivers, which drain to the Saldaña River. All localities are within the Magdalena River basin. The first location is on the western slope of the Eastern Cordillera of Colombia and the last two localities are on the eastern slope of the Cordillera Central (Figure 3).

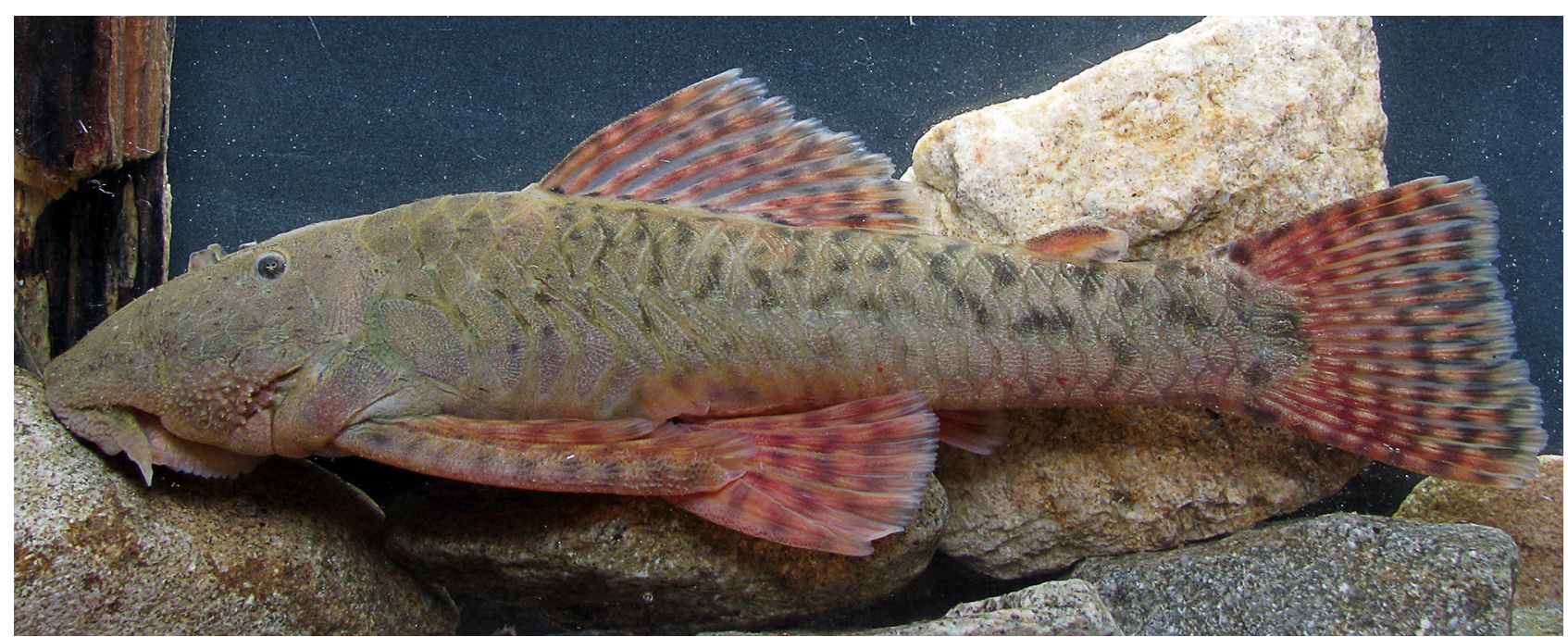

FIGURE 2. Cordylancistrus pijao. Live specimen (Photo by Yesid López-Pinto)

Etymology. The name "pijao" is treated as a noon in apposition and refers to the native indigenous people, symbol of the Tolima department, who preferred to die rather than submit to Spanish monarchy.

Ecological notes. The quebrada Aguas Blancas has a gravel and sand bottom, and in the area of its mouth in the Cuide Blanco River has mainly moderate-sized rocks that allow the formation of small backwaters. The average temperature is $18^{\circ} \mathrm{C}$, with a slightly basic $\mathrm{pH}(8.1)$ and moderate conductivity $(192.8 \mu \mathrm{S})$. The area is characterized by the presence grazing zones and small coffee farms. The original forests have been felled, and zones at different stages of secondary succession are found. At the stream's mouth, it is possible to observe some large trees (common name caracolí) and some shrubs. 


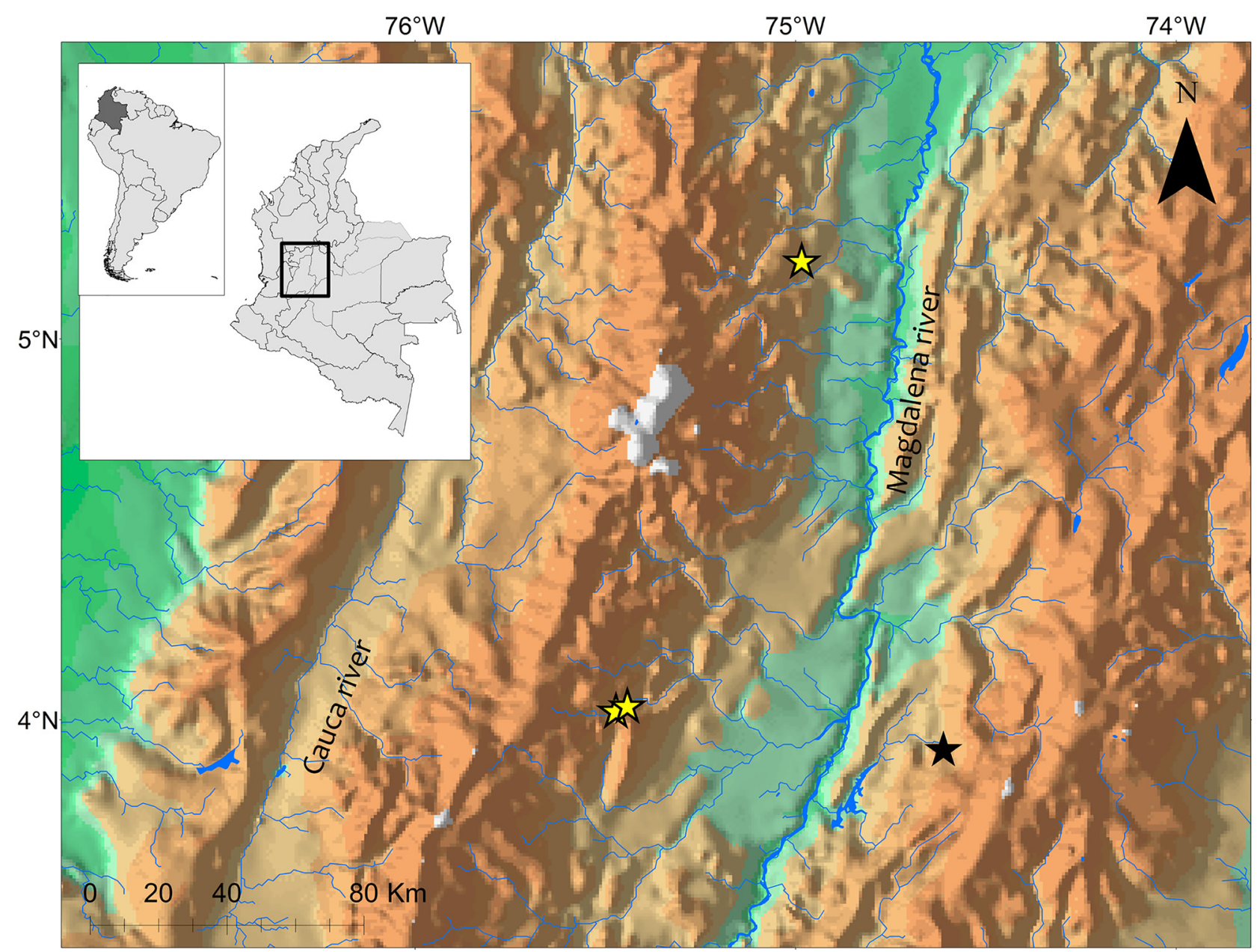

FIGURE 3. Map of Colombia showing the capture localities of Cordylancistrus pijao, black star type locality, yellow stars other localities.

\section{Discussion}

The external characters and morphology of $C$. pijao unambiguously indicate that the species belongs within the Chaetostoma group; dorsal-fin with eight branched rays, dentary very wide, equal or greater than interorbital distance and belly naked. Inside the Chaetostoma group, is more similar to some species of Cordylancistrus; snout is covered with plates $v s$. naked snout, in species of Chaetostoma and Transancistrus; adipose and anal fins present $v s$. adipose and anal fins absent, in species of Leptoancistrus; longest movable cheek odontode no reaching pectoral-fin origin and pectoral-fin spine relatively short, no passing half of length of pelvic-fin spine $v s$. longest movable cheek odontode passing pectoral-fin origin and pectoral-fin spine relatively long, reaching end of pelvicfin spine, in species of Dolichancistrus. It has some similarities to Andeancistrus species, but lacks keels on body side plates $v$ s. keels on body side plates present in A. platycephalus, and has significant differences in morphometrics with A. eschwartzae (Table 2). Morphologically, C. pijao most resembles C. daguae, C. nephelion and C. perijae, but exhibits clear differences with C. torbesensis (type species of the genus), and C. platyrhynchus as described in the diagnosis. In fact, almost all the species placed in Cordylancistrus show differences with $C$. torbesensis and C. platyrhynchus. Despite the uncertain status of Cordylancistrus (Armbruster, 2004, 2008; Lujan et al., 2015a, b) we consider it most appropriate to tentatively place this new species in Cordylancistrus, until an analysis that includes all the species included in it is completed. One of the diagnostic characters of Andeancistrus is its lack of cheek odontodes that extend past the opercular flap (Lujan, Meza-Vargas \& Barriga-Salazar, 2015). But, C. daguae, C. nephelion, C. perijae and C. pijao also lack cheek odontodes that extend past the opercular flap. Between species assigned to Cordylancistrus, only $C$. torbesensis has cheek odontodes that extend past the 
opercular flap. This character also occurs in species included in Dolichancistrus and Leptoancistrus (Meek \& Hildebrand, 1916; Dahl, 1964; Isbrücker 1980), suggesting that the type species of the genus Cordylancistrus is in fact more related to species of the genera Dolichancistrus and Leptoancistrus, as observed in proposed phylogenetic hypotheses (Armbruster, 2004, 2008; Lujan et al., 2015a, b).

The combination of morphological characters (presence of clearly movable odontodes at the cheek region, and a more robust or deeper body, see Table 2) make it easy to differentiate $C$. pijao from its congeners within Colombia. The geographic distributions of the three species of Cordylancistrus that inhabit in Colombia, $(C$. daguae - Pacific versant, C. pijao - Magdalena valley, and C. platyrhynchus - Amazonas River basin) show that the diversification of the genus is likely related to the evolution of the Andes Mountains of Colombia. This is the first record of a species of Cordylancistrus within the Magdalena River basin, but descriptions of one or two more new species from the basin are being prepared.

TABLE 2. Comparative morphometric data in \% of standard length, from some species of Andeancistrus and Cordylancistrus.

\begin{tabular}{|c|c|c|c|c|c|c|c|c|c|c|c|c|}
\hline & \multicolumn{2}{|c|}{$\begin{array}{l}\text { A. platycephalus } \\
\mathrm{n}=8\end{array}$} & \multicolumn{2}{|c|}{$\begin{array}{l}\text { A. eschwartzae } \\
\mathrm{n}=10\end{array}$} & \multicolumn{2}{|c|}{$\begin{array}{l}\text { C. daguae } \\
\mathrm{n}=9\end{array}$} & \multicolumn{2}{|c|}{$\begin{array}{l}\text { C. perijae } \\
\mathrm{n}=9\end{array}$} & \multicolumn{2}{|c|}{$\begin{array}{l}\text { C. nephelion } \\
\mathrm{n}=7\end{array}$} & \multicolumn{2}{|c|}{$\begin{array}{l}\text { C. pijao } \\
\mathrm{n}=10\end{array}$} \\
\hline & Min & Max. & Min & Max. & Min & Max. & Min & Max. & Min & Max. & Min & Max. \\
\hline Standard length (mm) & 75.0 & 115.4 & 82.2 & 141.5 & 32.3 & 88.3 & 33.4 & 127.3 & 31.1 & 129.1 & 41.3 & 151.6 \\
\hline Head length & 34.4 & 37.5 & 34.8 & 37.6 & 32.0 & 38.1 & 35.9 & 39.4 & 34.3 & 41.2 & 31.3 & 35.8 \\
\hline Predorsal length & 45.4 & 50.6 & 44.3 & 49.0 & 44.2 & 49.3 & 47.9 & 51.7 & 42.9 & 46.6 & 43.1 & 47.3 \\
\hline Postdorsal length & 29.4 & 35.4 & 31.3 & 34.9 & 26.8 & 31.2 & 31.9 & 35.0 & 35.0 & 37.7 & 34.6 & 39.8 \\
\hline Interdorsal length & 12.6 & 15.5 & 12.0 & 15.9 & 9.2 & 13.1 & 14.4 & 17.8 & 10.1 & 15.3 & 14.6 & 17.9 \\
\hline Preanal length & 68.4 & 72.8 & 69.8 & 72.7 & 69.6 & 76.2 & 68.9 & 73.4 & 64.1 & 69.5 & 68.0 & 74.7 \\
\hline Postanal length & 22.0 & 28.6 & 25.7 & 28.6 & 22.5 & 26.2 & 23.3 & 31.5 & 28.4 & 35.1 & 26.9 & 29.3 \\
\hline Thoracic length & 21.5 & 27.3 & 22.1 & 27.5 & 21.0 & 26.1 & 19.8 & 24.7 & 20.6 & 23.4 & 22.0 & 25.9 \\
\hline Abdominal length & 20.4 & 23.4 & 21.1 & 24.4 & 21.7 & 26.1 & 21.0 & 23.7 & 19.6 & 24.0 & 21.3 & 24.5 \\
\hline Dorsal fin base & 23.8 & 26.8 & 22.8 & 27.9 & 23.1 & 27.0 & 22.5 & 25.7 & 18.5 & 22.5 & 21.3 & 24.9 \\
\hline Dorsal spine length & 20.7 & 25.0 & 18.4 & 23.1 & 18.5 & 23.5 & 22.2 & 25.1 & 21.3 & 25.5 & 18.7 & 23.6 \\
\hline Pectoral spine length & 24.4 & 29.3 & 25.7 & 30.9 & 24.5 & 34.1 & 24.6 & 36.5 & 24.8 & 33.0 & 23.0 & 34.9 \\
\hline Pelvic spine length & 18.8 & 21.8 & 17.4 & 21.6 & 20.4 & 25.8 & 21.4 & 24.1 & 25.0 & 27.3 & 21.6 & 24.7 \\
\hline Cleithral width & 35.7 & 39.3 & 37.4 & 40.8 & 32.5 & 37.9 & 34.0 & 40.8 & 32.8 & 36.2 & 30.3 & 37.7 \\
\hline Caudal peduncle depth & 9.8 & 11.9 & 11.1 & 12.3 & 9.9 & 11.8 & 9.6 & 11.5 & 12.5 & 14.6 & 9.5 & 12.4 \\
\hline Head depth & 16.5 & 20.0 & 17.6 & 19.8 & 14.6 & 17.7 & 17.4 & 19.0 & 17.2 & 20.2 & 16.4 & 18.9 \\
\hline Snout length & 23.3 & 26.2 & 23.7 & 26.2 & 20.8 & 24.7 & 24.0 & 27.3 & 23.1 & 25.0 & 21.4 & 24.0 \\
\hline Interorbital width & 9.1 & 10.3 & 8.6 & 9.9 & 9.8 & 13.2 & 9.8 & 11.1 & 9.6 & 11.3 & 8.6 & 10.8 \\
\hline Orbital diameter & 3.9 & 4.9 & 3.9 & 5.1 & 3.8 & 5.2 & 4.1 & 6.3 & 4.8 & 6.4 & 2.7 & 3.9 \\
\hline Mandibular ramus length & 11.1 & 12.5 & 11.6 & 12.8 & 8.1 & 10.4 & 10.0 & 13.0 & 9.6 & 11.1 & 8.4 & 10.2 \\
\hline
\end{tabular}

\section{Material examined}

Andeancistrus eschwartzae: MEPN-11196, 15 ex., 82.2-141.5 mm SL, Ecuador, Morona Santiago Province, Río Amundal afluente del río Palora, approx. $01^{\circ} 44^{\prime} 45^{\prime \prime}$ S $78^{\circ} 02^{\prime} 58^{\prime \prime}$ W, N. Lujan, D. Taphorn \& R. Barriga, 08 September 2012.

Andeancistrus platycephalus: ANSP-153645, 2 ex., 86.6-115.4 mm SL, Ecuador (S.E.), Chiguaza River, Cutucu mountain, elevation 1075 m, R. M. Peck, 18 June 1984. FMNH-97429, 1 ex., 90.1 mm SL, Ecuador, Zamora-Chinchipe, Zamora River system, Quebrada Tunantza, approx. 040'30”S, 78 $53^{\circ} 05^{\prime} \mathrm{W}$, R. Barriga, M. Ibarra, Lema, 15 March 1979. MEPN-11418, 6 ex., 75.4-96.5 mm SL, Ecuador, Morona Santiago Province, Río 
Yungantza near Limón community, approx. 02 58'27’S, 78²6’49”'W, D. Taphorn, N. Lujan \& R. Barriga, 04 September 2012. MEPN-18597, 3 ex., 109.8-133.5 mm SL, Ecuador, Zamora Province, Rio Blanco, in front house of Andrade family, approx. 0348'04”S, 78³3'59”W, R. Barriga, J. Sharupe \& J. Sandoval, 07 October 2008.

Chaetostomus platycephalus: BMNH-1898.11.4.42, Holotype, $110.3 \mathrm{~mm}$ SL, Ecuador (eastern), Bomboiza River, upper Amazon River basin.

Cordylancistrus daguae: IMCN-1285, 3 ex., 66.0-88.3 mm SL, Colombia, Departamento del Valle, Aguaclara

River, near the confluence with Anchicayá River, A. Ortega-Lara, 14 July 2002.

Cordylancistrus nephelion: MBUCV-V-21800, Holotype, $129.1 \mathrm{~mm}$ SL, Venezuela, Miranda State, Caribbean

Sea basin, Tuy River system, Mesia River, tributary of the Guare River, near Village Corocito, approx. $10^{\circ} 10^{\prime} \mathrm{N}$, 6705’ W, N. Padilla \& H. Camejo, 26 January 1992. MBUCV-V-27872, Paratype, $61.0 \mathrm{~mm}$ SL; Venezuela, Caribbean Sea basin, Miranda State, Tuy River system, Mesia River, near El Salado, approx. $10^{\circ} 12^{\prime} \mathrm{N}, 67^{\circ} 03^{\prime} \mathrm{W}$, N. Padilla \& H. Camejo, 29 May 1994.

Cordylancistrus perijae: MBUCV-V-21747, 7ex., Paratypes, 32.4-121.3 mm SL, Venezuela, Zulia state, Maracaibo Lake basin, Sierra de Perijá, Caño Colorado, tributary to the Palmar River, 100 meters from the dam site (under construction), approx. $10^{\circ} 37^{\prime} 12^{\prime}$ 'N 72 $25^{\prime} 34^{\prime}$ 'W, elevation $150 \mathrm{~m}$, C. Casler, J. Toledo \& W. Villalobos, 11 July 1989.

Cordylancistrus platyrhynchus: MBUCV-V-32672, 4 ex., 48.8-67.7 mm SL, Colombia, Putumayo, Mocoa, Sangoyaco River, J. Maldonado, 06 Mar. 2005. IAvH-5252, 1 ex., 74.0 mm SL, Colombia, Putumayo, Mocoa River, Finca La Cascada, J. Maldonado, 07 March 2005.

Cordylancistrus santarosensis MECN-DP-2061, Holotype, $70.8 \mathrm{~mm}$ SL: Ecuador, El Oro Province, Santa Rosa River, Limón, Playas, approx. 03³4’10”S, 7956’34.5”W, Windsor Aguirre, 09 Jul. 2008.

Cordylancistrus torbesensis MBUCV-V-29430 (ex. MCNG-8066), 1 ex., $57.4 \mathrm{~mm}$ SL, Venezuela, Táchira State, Torbes River, $5 \mathrm{~km}$ before Táriba, approx. 0750’ $\mathrm{N} 72^{\circ} 10^{\prime} \mathrm{W}$, D. Taphorn \& C. Lilyestron, 27 May 1982. MBUCV-V-29432 (ex. MCNG-43287), 5 ex., 27.9-67.9 mm SL, Venezuela, Táchira State, Quinimari River, before confluence into Torbes River, approx. 07³7’N 72¹0’W, S. Usma \& L. Vasquez, 02 November 1999.

Hemiancistrus daguae: FMNH-56052, Holotype, 60.4 mm SL, Colombia, Caldas. FMNH-56053, Paratypes, 3 ex., 32.3-75.8 mm SL, Colombia, Caldas. FMNH-56054, Paratypes 2 ex., 33.6- 65.9 mm SL, Colombia, Caldas.

Hemiancistrus platyrhynchus: ANSP-70512, Holotype, $70.7 \mathrm{~mm}$ SL, Colombia, Florencia, Orteguasa River basin, Brother Niceforo Maria, 1931. ANSP 70513, Paratype, $67.75 \mathrm{~mm}$ SL, Colombia, Florencia, Orteguasa River basin, Brother Niceforo Maria, 1931. MBUCV-V-18376 (ex. ANSP-84570), 3 ex. 37.4-56.1 mm SL, Colombia, Brother Niceforo Maria, 1931.

Pseudancistrus torbesensis: MBUCV-V-18374 (ex. USNM-121002), 5 Paratypes, 23.8-51.8 mm SL, Venezuela, Táchira State, Orinoco River basin, Apure River system, Torbes River, 1 kilometer above Táriba, tributary to Uribante River, approx. $07^{\circ} 50^{\prime} \mathrm{N} 72^{\circ} 20^{\prime} \mathrm{W}$, L. P. Schultz, 31 Mar. 1942.

Transancistrus aequinoctiale: MEPN-8805, 3 ex., 79.1-84.1 mm SL, Ecuador, Imbabura Province, Aguas Claras, Altos del Río Guayllabamba, approx. 00¹4’05”N 7848’50”W, M. Olalla, Sep. 1961. MEPN-18600, 3 ex., 83.4-112.7 mm SL, Ecuador, Pichincha Province, Río Pachijal afluente del Guayllabamba, approx. 0001'10" N 7847’12” W, M. Olalla, Aug. 1969.

Transancistrus santarosensis: MEPN-11220, 4 ex., 26.3-52.0 mm SL, Ecuador, El Oro Province, Santa Rosa River, near Bado, approx. 03`33’31'S, 7956’48”W, N. Lujan, D. Taphorn \& R. Barriga, 29 Aug. 2012. MBUCVV-35694, 4 ex. 62.5-94.6 mm SL, Ecuador, Bolívar Province, Guayas River basin, Vinces River system, Caluma river, near Guaranda, Without additional data.

\section{Acknowledgments}

This work was partially supported by the All Catfish Species Inventory project funded by the U.S.A. National Science Foundation (DEB-0315963) awarded to FPR. Corporación Autónoma Regional del Tolima "CORTOLIMA" and Comité Central de Investigaciones de la Universidad del Tolima awarded funds to FAVN. Our thanks to the following institutions: Colección de Peces, Instituto Alexander von Humboldt, Villa de Leyva, Colombia. Colección de Peces, Instituto de Ciencias Naturales, Universidad Nacional, Bogotá, Colombia. Colección de Peces del Museo de la Escuela Politécnica Nacional, Instituto de Ciencias Biológicas, EPN, Quito, 
Ecuador. Field Museum of Natural History, Chicago, USA. Academy of Natural Science, Philadelphia, USA. British Museum of Natural History, London, UK. To Yesid López P. for providing specimens of C. pijao collected by him and for the excellent photo of live specimen. Thanks to Jonathan Armbruster (Auburn University), Nathan Lujan and a anonymous reviewer for a critical review and comments of the manuscript. To L. J. Garcia-Melo and J. E. Melo Garcia from the Research Group in Zoology, Tolima University, to Alberto Marcano, Colección de Peces del Museo de Biología, IZET-UCV, Caracas, Venezuela, and to Vladimir Carvajal López, Instituto de Ciencias Biologicas, Escuela Politecnica Nacional, Quito, Ecuador. Thanks to German Galvis, José Ivan Mojica, Javier Maldonado, Luz Fernanda Segura, Saul Prada, Saulo Usma, Ramiro Barriga, Richard Vari, Barry Chernoff, Bill Saul, and Scott Schaefer. They provided facilities and logistical support during FPR visits to collections.

\section{References}

Armbruster, J.W. (2004) Phylogenetic relationships of the suckermouth armored catfishes (Loricariidae) with emphasis on the Hypostominae and Ancistrinae. Zoological Journal of the Linnaean Society, 141 (1), 1-80. https://doi.org/10.1111/j.1096-3642.2004.00109.x

Armbruster, J.W. (2008) The genus Peckoltia with the description of two new species and a reanalysis of the phylogeny of the genera of the Hypostominae (Siluriformes: Loricariidae). Zootaxa, 1822, 1-76.

Ballen, G.A. (2011) A new species of Chaetostoma Tschudi (Siluriformes: Loricariidae) from Colombia with a definition of the C. anale species group. Papéis Avulsos de Zoologia, 51 (26), 383-398.

Boeseman, M. (1968) The genus Hypostomus Lacépède, 1803, and its Surinam representatives (Siluriformes, Loricariidae). Zoologische Verhandelingen, 99, 1-89.

Boulenger, G.A. (1898) Viaggio del Dr. Enrico Festa nell'Ecuador e regioni vicine. Poissons de l' Equateur (première partie). Bollettino dei Musei di Zoologia ed Anatomia Comparata della R. Università di Torino, 13, 1-13.

Dahl, G. (1964) La ictiofauna del río San Jorge. In: Dahl, G., Medem, F. \& Ramos Henao, A. (Eds.), El Bocachico, contribución al estudio de su biología y de su ambiente. Departamento de Pesca de la Corporación Autónoma Regional de los Valles del Magdalena y del Sinú, C.V.M. Talleres Gráficos Banco de la República de Colombia, Bogotá, pp. 1-144.

Eigenmann, C.H. (1912) Some results from an ichthyological reconnaissance of Colombia, South America. Part I. Indiana University Studies, 16 [sic no. 8], 1-27.

Fowler, H. (1943) A collection of fresh-water fishes from Colombia, obtained chiefly by Brother Nicéforo Maria. Proceedings of the Academy of Natural Sciences of Philadelphia, 95, 223-266.

Isbrücker, I.J.H. (1980) Classification and catalogue of the mailed Loricariidae (Pisces, Siluriformes). Verslagen en Technische Gegevens, Instituut voor Taxonomische Zoölogie, Universiteit van Amsterdam, 22, 1-181.

Lujan, N.K., Meza-Vargas, V. \& Barriga-Salazar, R. (2015) Two new Chaetostoma Group (Loricariidae: Hypostominae) sister genera from opposite sides of the Andes mountains in Ecuador, with the description of one new species. Copeia, 103 (3), 651-663. https://doi.org/10.1643/CI-15-246

Lujan, N.K., Armbruster, J.W., Lovejoy, N. \& López-Fernández, H. (2015a) Multilocus molecular phylogeny of the suckermouth armored catfishes (Siluriformes: Loricariidae) with a focus on subfamily Hypostominae. Molecular Phylogenetics and Evolution, 62, 269-288. https://doi.org/10.1016/j.ympev.2014.08.020

Lujan, N.K., Meza-Vargas, V., Astudillo-Clavijo, V., Barriga-Salazar, R. \& López-Fernández, H. (2015b) A multilocus molecular phylogeny for Chaetostoma clade genera and species with a review of Chaetostoma (Siluriformes: Loricariidae) from the Central Andes. Copeia, 103 (3), 664-701. https://doi.org/10.1643/CI-14-194

Meek, S.E. \& Hildebrand, S.F. (1916) The fishes of the freshwaters of Panama. Field Museum of Natural History, Publications, Zoological Series, 10 (15), 1-374, pls. 6-32.

Pellegrin, J. (1909) Mission géodésique de l'Équateur. Collections recueillies par M. le Dr. Rivet. Description de deux poissons nouveaux de la famille des Loricariidae. Bulletin du Muséum National d'Histoire Naturelle, Série 1, 15 (8), $517-519$.

Pérez, A. \& Provenzano R., F. (1996) Cordylancistrus perijae, a new species of armored catfish (Siluroidei, Loricariidae) from the Maracaibo Basin, Venezuela. Studies on Neotropical Fauna and Environment, 31 (1), 27-34. https://doi.org/10.1076/snfe.31.1.27.13317

Provenzano, F. \& Milani, N. (2006) Cordylancistrus nephelion (Siluriformes, Loricariidae), a new and endangered species of armored suckermouth catfish from the Tuy River, north-central Venezuela. Zootaxa, 1116, 29-41.

Rapp Py-Daniel, L.H. (1991) Chaetostoma jegui, a new mailed catfish from the rio Uraricoera, Brazil (Osteichthys: Loricariidae). Ichthyological Exploration of Freshwaters, 2, 239-246.

Sabaj, M.H. (2016) Standard symbolic codes for institutional resource collections in herpetology and ichthyology: an Online Reference. Version 6.5 (16 August 2016). Electronically accessible. American Society of Ichthyologists and Herpetologists, Washington, DC. Available from: http://www.asih.org/ (accessed 4 July 2017)

Schultz, L.P. (1944) The catfishes of Venezuela, with descriptions of thirty-eight new forms. Proceedings of the United States National Museum, 94 (3172), 173-338, pls. 1-14.

Tan, M. \& Armbruster, J.W. (2012) Cordylancistrus santarosensis (Siluriformes, Loricariidae), a new species with unique snout deplatation from the Río Santa Rosa, Ecuador. Zootaxa, 3243, 52-58. 